\title{
Occurrence of Rust of Pangola Grass in Puerto Rico
}

\author{
Lii-Jang Liu ${ }^{1}$
}

\section{INTRODUCTION}

Pangola grass, Digitaria decumbens Stent, has become an important grass for pasture in Puerto Rico. About 150,000 acres are planted to this grass because of its high quality and productivity. No diseases have been reported on Pangola grass in Puerto Rico since its recent introduction from Africa. During the last few years, a rust has caused serious damage to foliage of Pangola grass throughout the Island. The malady was found in pastures in the Corozal and Río Piedras areas. Since Pangola is one of Puerto Rico's major pasture grasses, this rust has caused concern. This paper reports findings on the causal organism, as well as on its pathogenicity and control.

\section{REVIEW OF THE LITERATURE}

During 1915-17. Arthur $(1,2,3)^{2}$ reported Puccinia substriata Ellis \& Barth. on a number of hosts from Puerto Rico, including Syntherisma digitata (Schwartz) Hitchc. The same author (4) later included Uredo paspalicola under the species of $P$. substriata. In 1941, Cummins (5) reported a New Guinea collection of Puccinia, occurring on the same host (Digitaria pruriens (Trin.) Buse) of Puccinia oahuensis Ell. \& Ev., as Puccinia digitariae. Apparently he did not give $P$. oahuensis consideration at that time. After having examined the telial collections obtained from Hawaii, the Philippines, New Guinea, India, Transvaal, Southern Rhodesia, Uganda, Brazil, and Puerto Rico, Cummins (6) concluded that all these collections of Puccinia from Digitaria represented a single species and should be designated as Puccinia oahuensis.

Although Cummins (7) reported in 1942 that Uredo paspalicola was synonymous with Angiopsora compressa and $P$. tubulosa was synonymous with $P$. substriata, he did not consider $P$. substriata a synonym of $P$. oahuensis because, in most collections, the urediospores of $P$. substriata tend to have the wall slightly thickened apically.

In 1963 Roure (11) reported from Puerto Rico P. oahuensis Ell. \& Ev.

${ }^{1}$ Associate Phytopathologist, Agricultural Experiment Station, Mayagüez Campus, University of Puerto Rico, Río Piedras, P.R. Special thanks are due Dr. G. B. Cummins, Head of the Department of Plant Pathology, Purdue University, West Lafayette, Indiana, and to Dr. J. Bird, Head of the Department of Plant Pathology and Botany, Agricultural Experiment Station, University of Puerto Rico for their invaluable advice in the preparation of this manuscript.

${ }^{2}$ Italic numbers in parentheses refer to Literature Cited, p. 139. 
on Digitaria sanguinales (L.) Scop. Without knowing that $P$. substriata is not synonymous with $P$. oahuensis, he grouped $P$. substriata, $P$. paspalicola (P. Henn.) Arth. and P. tubulosa (Pat. \& Gaill.) Arth. under the species of P. oahuensis.

Recently Ramachar and Cummins (10) made an extensive study of the species of Puccinia on the Paniceae. They failed to record a single rust species on Pangola grass.
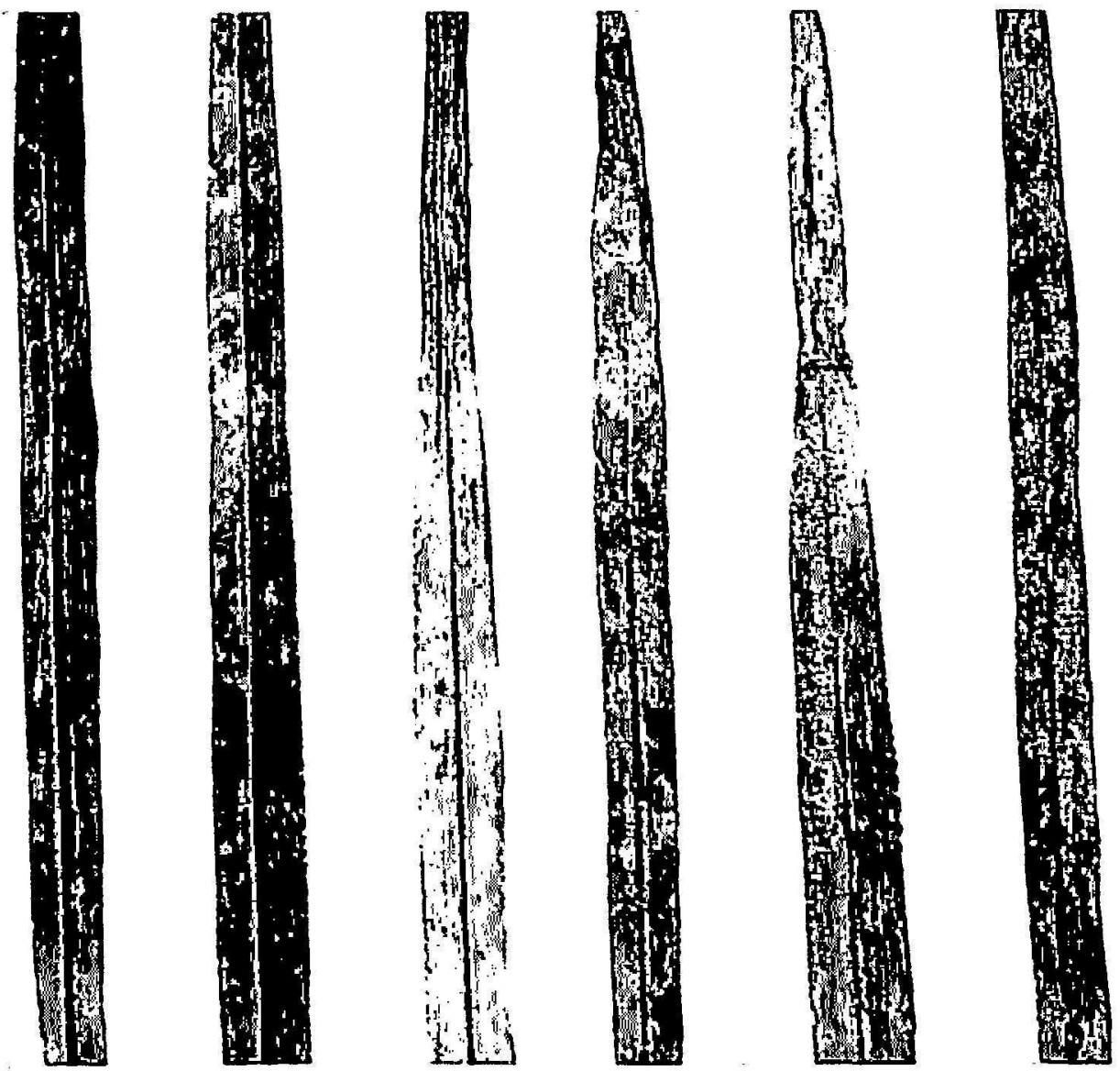

Fra. 1.-Symptoms of the rust disense on Pangola grass leaves.

\section{RESUL'TS}

\section{DESCRIPTION OF SYMPTOMS}

In the early stage, the affected plants show minute, irregular, yellowish brown to orange-brown spots. These spots increase in size and gain a paleyellow halo. The lesions are usually $0.5 \mathrm{~mm}$. in length, but occasionally may reach $1.0 \mathrm{~mm}$. (fig. 1). The lesions rapidly take on a pustular appearance, When the disease is severe, considerable numbers of pustules develop on the leives. These pustules usually coalesce and form large, irregular necrotic areas. Most of the affected leaves died prematurely. 


\section{IDENTIFICATION OF THE CAUSAL ORGANISM}

Microscopic examination of the lesions revealed the presence of a rust of the genus Puccinia with the following characteristics:

The uredia are subepidermal, and rupture the epidermis under pressure to release the dense masses of orange-colored urediospores. Urediospores are obovate, golden-brown, coarsely and strongly echinulate and are 2.38 to $34 \mu$ long x 20.4 to $27.2 \mu$ wide (fig. 2). Urediospores have four or five equatorial pores.

The telia are small and remain long covered by the epidermis of the host. The teliospores are clavate, slightly constricted at the septum, closely compacted, and measure 35.7 to $66.3 \mu$ long $\times 17$ to $35.7 \mu$ wide. The walls of

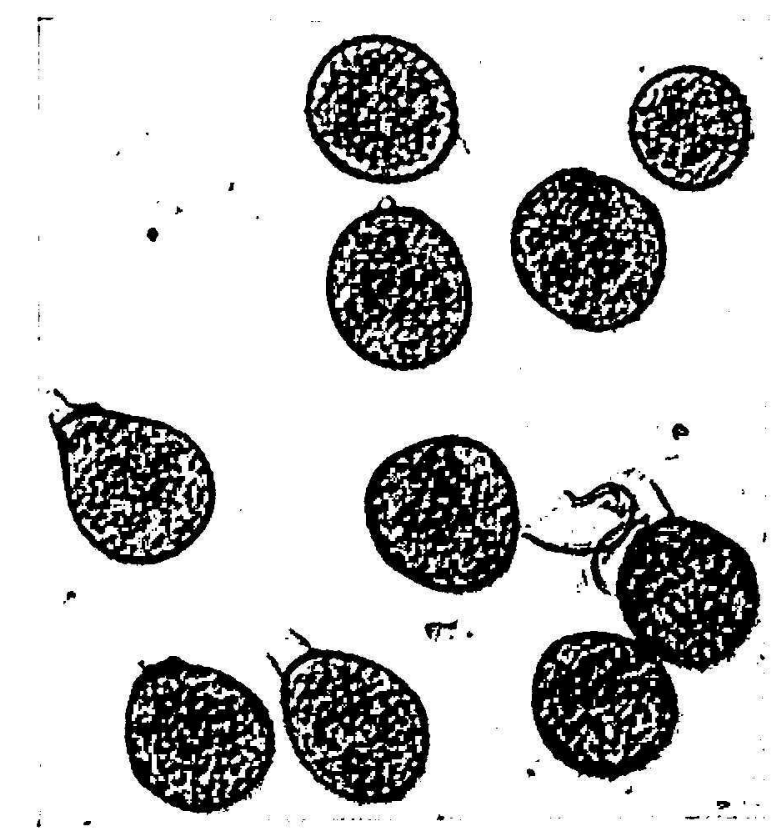

Fıc. 2.-Urediospores of Puccinia oahuensis var. digitaria-derumbensis.

teliospores are chestnut-brown above, lighter below and thickened 1.7 to $5.1 \mu$ at the apex. Pedicels of teliospores are golden to brown and short (figs. 3 and 4).

\section{PATHOGENICITY TEST}

Healthy leaves of 30 clones of different species and varieties of Digitaria were removed and placed in separate petri dishes $(80 \mathrm{~cm}$. diameter) each containing $30 \mathrm{ml}$. of 30 p.p.m. of Benzimidazole. Collection of rust from Pangola grass was "purified" by transferring single urediospores to leaves of Pangola grass plants which had been raised from presumably spore-free sets. Erediospores were sprayed on the surface of the leaves with an aid of a steam-sterilized atomizer. For each species or variety of Digitaria, 10 leaves were inoculated with the various rust isolates. The test was repeated once. 
Pustules appeared 7 to 10 days after inoculation, and reaction types were observed from 10 to 14 days after inoculation. Reaction types under field conditions were also recorded.

As shown in table 1 , in most cases, the observed field infection types correspond with those of artificial inoculation. Some clones of Digitaria decumbens such as P.R. P.I. No. 6438 and 6535 exhibited a high degree of

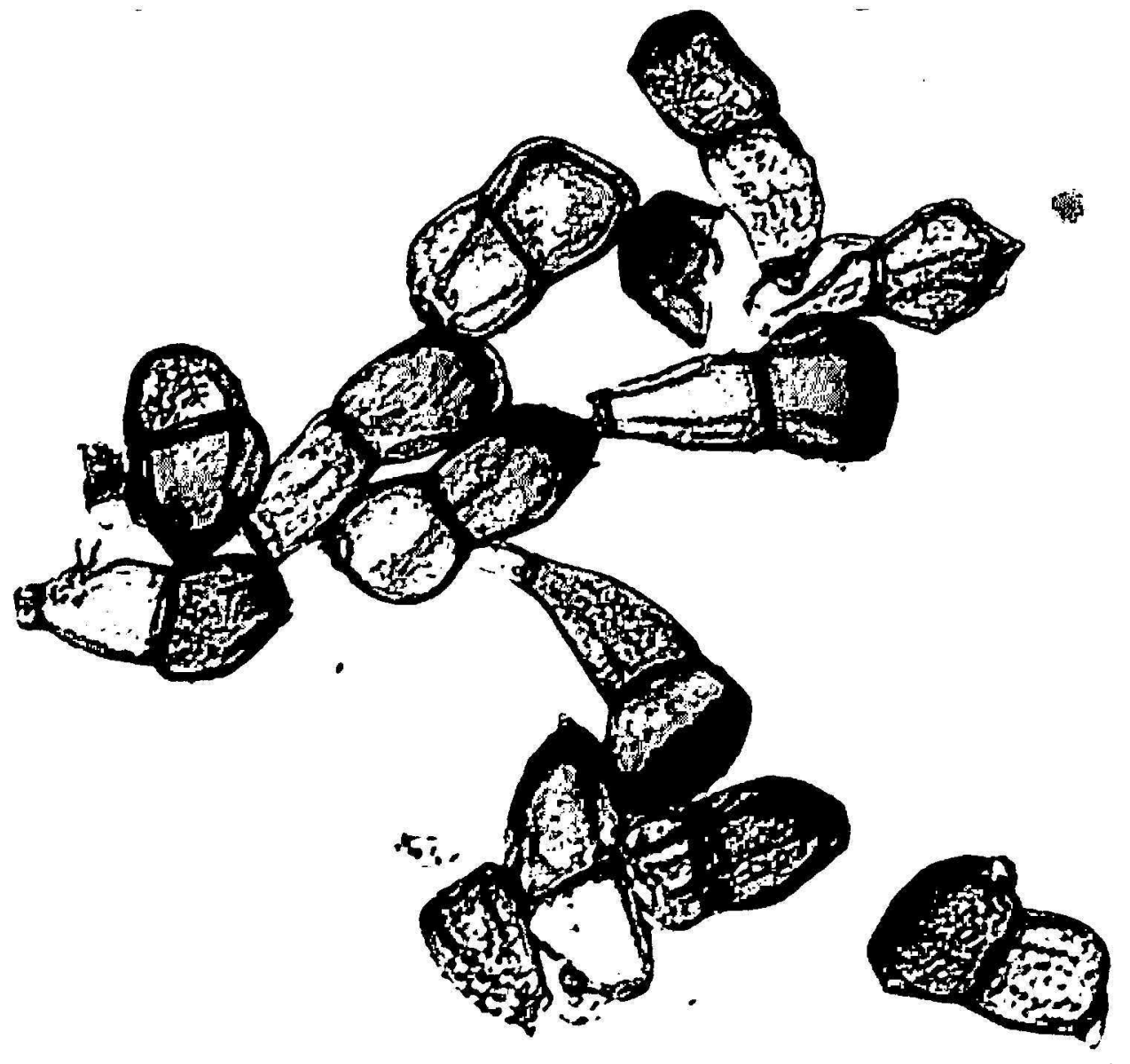

Fra. 3.-Teliospores (from dry specimen) of Pucrinia oahuensis var. digilariadecumbensis.

resistance to the Pangola rust while others such as U.S.D.A. P.I. No. 111110 were found to be highly susceptible.

\section{CHEMICAL CONTROL}

Five chemicals, Daconil ${ }^{3}$, Dyrene ${ }^{4}$, Dithane M-455, Bay $47531^{6}$, and Cycoce $^{7}$ were applied as a foliar spray at $0.05,0.1,0.2,0.3$ and 0.4 percent,

${ }^{3}$ Daconil 2787 -Tet rachloro isophthalonitrile; ${ }^{4}$ Jyrene, a foliage fungicide, 2,4Dichloro-6-o-chloroanilino-s-triazine; ${ }^{5}$ Dithane $\mathrm{M}-45$-coordination product of zinc ion and manganese ethylene bisdithiocarbamate; ${ }^{6}$ Bay $47531-\mathrm{N}$-(Dichlorofluoro methylthio)- $\mathrm{N}^{\prime}, \mathrm{N}^{\prime}$-dimethyl-N-phenylsulfamide; ${ }^{2}$ Cycocel-plant growth regulant (2-Chlomethyl) trimethyl ammonium chloride. 
in each case on leaves of the Pangola grass which had been previously inoculated with the urediospores of the Pangola rust and shown good symptoms of the disease. Three replications were made for each treatment. Plants sprayed with water were included as controls. Observations were made 3 weeks after plants were treated.

Results obtained indicated that Dithane $\mathrm{M}-45$ is the most effective chemical for delaying pustule appearance. At 0.3 to 0.4 percent concentration, M-45 is effective in delaying pustule appearance by $\$ 0$ percent for a period of 3 weeks. Daconil, Dyrene, and Bay 47531, even at 0.4 percent,

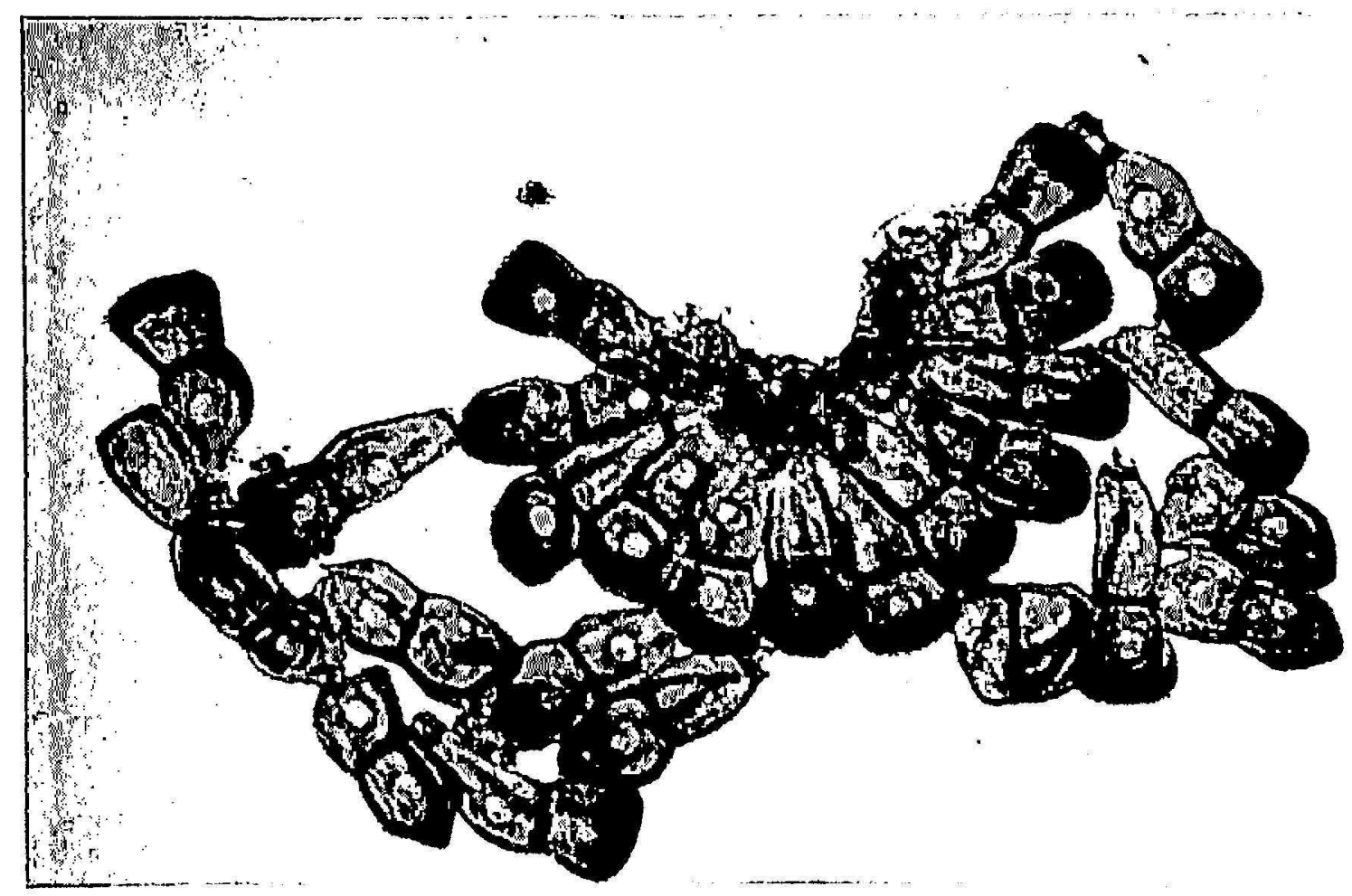

Fic. 4.-Teliospores (from fresh specimen) of Puccinia oahuensis var. digilariadecumbensis.

had little effect on pustule appearance (approximately 20 to 30 percent for a period of 2-3 weeks). Lnder the condition of our tests Cycocel had no effect.

\section{DISCUSSION AND CONCLUSION}

The results obtained in these studies indicated that the characteristic, compacted, and long-covered telia of the Pangola rust resemble that of $P$. oahuensis. However, the size of the urediospores and the teliospores is so variable that Ramachar and Cummins (10) grass rust key can hardly be used to identify this Pangola rust.

According to Ramachar and Cummins (10), the urediospores of Puccinia 
Table 1.-Pathogenicity of Puccinia oahuensis on Digitaria spp.

\begin{tabular}{|c|c|c|c|c|}
\hline \multirow{2}{*}{ Species } & \multirow{2}{*}{$\begin{array}{l}\text { U.S.D.A.A. } \\
\text { P.I. No. }\end{array}$} & \multirow{2}{*}{$\begin{array}{l}\text { P.R.P.I. } \\
\text { No. }\end{array}$} & \multicolumn{2}{|c|}{ Degree of infection } \\
\hline & & & $\begin{array}{c}\text { Artificial } \\
\text { inoculation }\end{array}$ & $\begin{array}{l}\text { Natural } \\
\text { infection }\end{array}$ \\
\hline $\begin{array}{l}\text { 1. D. milangiana } \\
\text { 2. Do. } \\
\text { 3. Do. } \\
\text { 4. Do. } \\
\text { 5. Do. } \\
\text { 6. Do. } \\
\text { 7. Do. sub. sp. eybesiana } \\
\text { 8. Do. } \\
\text { 9. Do. } \\
\text { 10. Do. } \\
\text { 11. Do. } \\
\text { 12. Do. } \\
\text { 13. Do. } \\
\text { 14. Do. } \\
\text { 15. Do. } \\
\text { 16. D. setivalva } \\
\text { 17. Do. } \\
\text { 18. D. smutsii } \\
\text { 19. Do. } \\
\text { 20. D. milangiana sub. sp. eybesiana } \\
\text { 21. D. decumbens } \\
\text { 22. Do. } \\
\text { 23. Do. } \\
\text { 24. D. eriantha } \\
\text { 25. D. valida } \\
\text { 26. D. pentzii } \\
\text { 27. Do. } \\
\text { 28. D. sp. } \\
\text { 29. Do. } \\
\text { 30. D. decumbens } \\
\text { (1) }\end{array}$ & $\begin{array}{r}299695 \\
299695 \\
299696 \\
(\text { A-23) } \\
299699 \\
299667 \\
299716 \\
299681 \\
299713 \\
299736 \\
299727 \\
299703 \\
299709 \\
299730 \\
299731 \\
299791 \\
299804 \\
299808 \\
299828 \\
299728 \\
299601 \\
(\text { A-24) } \\
299837 \\
299875 \\
299742 \\
299752 \\
299892 \\
- \\
111110\end{array}$ & $\begin{array}{l}6464 \\
6427 \\
6429 \\
5125 \\
6543 \\
6610 \\
6482 \\
6494 \\
6613 \\
6658 \\
6628 \\
6378 \\
6391 \\
6415 \\
6416 \\
6471 \\
6537 \\
6373 \\
6434 \\
6408 \\
6438 \\
5124 \\
6535 \\
5277 \\
6433 \\
6405 \\
6439 \\
6402 \\
6523 \\
-\end{array}$ & $\begin{array}{c}0 \\
3-4^{* 1} \\
0 \\
3 \\
0 \\
0 \\
0 \\
0 \\
0 \\
0-2 \\
0 \\
0 \\
0 \\
0 \\
0 \\
0 \\
0 \\
0 \\
0 \\
0 \\
0 \\
1-3 \\
0 \\
2-3 \\
0 \\
0 \\
0 \\
0 \\
1-3 \\
2-3\end{array}$ & $\begin{array}{c}0 \\
3-4 \\
0 \\
1 \\
0 \\
0 \\
0 \\
0 \\
0 \\
0 \\
0 \\
0 \\
0 \\
0 \\
0 \\
0 \\
0 \\
0 \\
0 \\
0 \\
0 \\
1-2 \\
0 \\
2-3 \\
0 \\
0 \\
0 \\
0 \\
0 \\
2-3 \\
0 \\
\end{array}$ \\
\hline
\end{tabular}

1 Infection types: 0, Immune-no rust pustules developed; 1 , very resistantrust pustules extremely small (less than $0.5 \mathrm{~mm}$. long); 2 , moderately resistant-. pustules small to medium (0.5-1.0 mm long); 3, moderately susceptible-pustules medium in size (1.0 mm. long); and 4, very susceptible-pustules large (more than $1.0 \mathrm{~mm}$. long) and often united.

oahuensis are mostly more than $29 \mu$ long and teliospores are mostly less than $45 \mu$ long. The urediospores of this rust, however, as shown in table 2, are mostly less than $29 \mu$ long and the teliospores mostly more than $45 \cdot \mu$ long. In view of this variation in spore size, and considering that the appearance of the urediospores and teliospores closely resembles that of $P$. oahuensis, the studied Pangola grass rust has tentatively been identified 
as a variant of Puccinia oahuensis, namely Puccinia oahuensis var. digitariadecumbensis.

The rust specimen obtained from Pangolagrass in the Rio Piedras area was also examined by Dr. F. D. Kern. In a recent letter to the author, Dr. Kern (13) stated: "About the rust on Pangola grass (Digitaria decumbens) I am still calling it Puccinia oahuensis. In this I have good company. I sent a specimen to Dr. Cummins and received this reply (June 2, 1967), ' I do agree with you that the rust of Digitaria decumbens is Puccinia oahuensis'."

The type specimen is preserved in the Department of Plant Pathology for future reference.

Although several investigators $(8,9,12)$ were able to delay pustule appearance of plant rusts by foliar application of Cycocel and certain systemic

TABite 2.-Frequency of distribution and size of the urediospores and teliospores of a variant of Puccinia oahuensis from Pangola grass

\begin{tabular}{c|c|c|c|c|c|c|c}
\hline \multicolumn{3}{c|}{ Urediospores } & \multicolumn{5}{c}{ Teliospores } \\
\cline { 5 - 8 } Length \\
$(\mu)$ & $\begin{array}{r}\text { Number } \\
\text { of } \\
\text { uredi- } \\
\text { ospores }\end{array}$ & $\begin{array}{c}\text { Width } \\
(\mu)\end{array}$ & $\begin{array}{c}\text { Number } \\
\text { of } \\
\text { uredi- } \\
\text { ospores }\end{array}$ & $\begin{array}{c}\text { Length } \\
(\mu)\end{array}$ & $\begin{array}{c}\text { Number } \\
\text { of } \\
\text { teli- } \\
\text { ospores }\end{array}$ & $\begin{array}{c}\text { Width } \\
(\mu)\end{array}$ & $\begin{array}{c}\text { Number } \\
\text { of } \\
\text { teli- } \\
\text { ospores }\end{array}$ \\
\hline $23.8-25.4$ & 2 & $20.4-22.0$ & 1 & $35.7-40.8$ & 4 & $17.0-22.1$ & 23 \\
$25.5-28.8$ & 25 & $22.1-23.0$ & 14 & $40.9-45.0$ & 6 & $22.2-25.5$ & 17 \\
$28.9-30.6$ & 16 & $23.1-25.0$ & 26 & $45.1-49.3$ & 14 & $25.6-28.9$ & 7 \\
$30.7-34.0$ & 7 & $25.1-27.2$ & 9 & $49.4-66.3$ & 26 & $29.0-35.7$ & 3 \\
\hline
\end{tabular}

fungicides, results obtained in these studies are not too satisfactory. Except for Dithane M-45, none of the chemicals tested effectively delayed appearance of pustule.

Since a great number of species and clones of Digitaria such as $D$. decumbensis P.R. P.I. No. 6438 and 6535 exhibited a high degree of resistance to the Pangola rust, replacing current susceptible clones with the resistant ones seems to be the best way to control the disease.

\section{SUMMARY}

Pangola grass (Digitaria decumbens Stent) rust was first observed in Puerto Rico at the Corozal Substation and then in the Solis farm at the Río Piedras Station. A study of the urediospore and teliospore morphology revealed that this Pangolagrass rust resembles Puccinia oahuensis Ell. \& Ev., except that the urediospores are shorter and the teliospores are longer. In view of this size variation, and considering the fact that the general appearance of the rust resembles that of $P$. oahuensis, the Pangola grass rust has tentatively been identified as a variant of $P$. oahuensis. 
Results of pathogenicity tests indicate that a great number of species or clones of Digitaria are resistant to the rust.

Among the chemicals tested, Dithane $M-45$ seemed to be the most promising for delaying the appearance and development of pustules.

\section{RESUMEN}

La roya de la yerba Pangola (Digitaria decumbens Stent) se observó por primera vez en Puerto Rico en la Subestación de Corozal y luego en la Finca Solis de la Estación Experimental Agrícola en Río Piedras. Un estudio sobre la morfología de las urediosporas y teliosporas reveló que esta roya de la yerba Pangola se parece a la Puccinia oahuensis Ell. \& Ev., excepto en que las urediosporas son más cortas y las teliosporas más largas.

En vista de esta variación en el tamaño y considerando el hecho de que la apariencia general de esta roya de la Pangola se parece a la de la $P$. oahuensis, fue que la roya de la Pangola se identificó tentativamente como una variante de la $P$. oahuensis.

Los resultados de la pruebas de patogenecidad indicaron que un gran número de especies o clones de la Digitaria son resistentes a esta roya.

Entre los agentes químicos que se probaron, tal parece que el Dithane M-45 es el que más promete en cuanto a demorar la aparición y desarrollo de las pústulas.

\section{LITERATURE CITED}

1. Arthur, J. C., Uredinales of Porto Rico based on collections by F. L. Stevens, Mycologia 7 (5): 227-55, 1915.

2. - Uredinales of Porto Rico based on collections by F. L. Stevens, Mycologia 8 (1): 16-33, 1916.

3. - Uredinales of Porto Rico based on collections by H. H. Whetzel, and E. W. Olive, Mycologia 9 (2): 55-104, 1917.

4. - New species of Uredineae XI, Bull. Torrey Botanical Club 46 (4): 107-25, 1919.

5. Cummins, G. B., Uredinales of New Guinea-III, Mycologia \$s: 143-54, 1941.

6. - Descriptions of tropical rusts-VI, Bull. Botanical Club 70 (5): 517-30, 1943.

7. - Revisionary studies in the tropical American rusts of Panicum, Paspalum, and Selaria, Mycologia S4: 669-95, 1942.

8. Hardison, J. R., Systemic activity of two derivatives of 1.4-Oxathin against smut and rust diseases of grass, Plant Dis. Reptr. 60 (8): 624, 1966.

9. Johnson, L. B., and Schafer, J. F., Effect of (2-chloroethyl) Trimethylammonium chloride on Puccinia recondita infection, Plant Dis. Reptr. 50 (2): 108-9, 1966.

10. Ramachar, P., and Cummins, G. B., The species of Puccinia on the Paniceae, Mycopathologia 25: 7-60, 1965.

11. Roure, Luis A., The rusts of Puerto Rico, Agr. Expt. Sta., Univ. P.R. Tech. Paper 35, pp. 91-7, 1963.

12. Tahori, A. S., Zeidler, G., and Hadery, A. H., Effect of some plant growth-retarding compounds on three fungal diseases and one viral disease, Plant $D$ is. Reptr. 49: 775-7, 1965.

13. Personal communication from Dr. F. D. Kern. 